\title{
Culture and extrinsic moral motives: comparisons of Japan residents and Japanese sojourners in individualistic and loose countries
}

\author{
$\operatorname{AUTHOR(S):~}$ \\ Takamatsu, Reina
}

\section{CITATION:}

Takamatsu, Reina. Culture and extrinsic moral motives: comparisons of Japan residents and Japanese sojourners in individualistic and loose countries. Culture and Brain 2021, 9(2): 112-127

\section{ISSUE DATE:}

2021-12

URL:

http://hdl.handle.net/2433/267850

\section{RIGHT:}

This version of the article has been accepted for publication, after peer review (when applicable) and is subject to Springer Nature's AM terms of use, but is not the Version of Record and does not reflect post-acceptance

improvements, or any corrections. The Version of Record is available online at: http://dx.doi.org/10.1007/s40167-02000095-1; The full-text file will be made open to the public on 07 June 2021 in accordance with publisher's 'Terms and Conditions for Self-Archiving'.:. This is not the published version. Please cite only the published version. この論文は出版 社版でありません。引用の際には出版社版をご確認じ利用ください。 
This document is the author deposited version.

You are advised to consult the publisher's version if you wish to cite from this version. Published article: Takamatsu, R., Min, M. C., Wang, L., Xu, W., Taniguchi, N., \& Takai, J. (2021). Moralization of Japanese cultural norms among student sojourners in Japan. International Journal of Intercultural Relations, 80, 242-249. https://doi.org/10.1016/j.ijintrel.2020.12.001

\title{
Culture and extrinsic moral motives: Comparisons of Japan residents and
} Japanese sojourners in individualistic and loose countries

\section{Reina Takamatsu, Ph.D.}

\section{Kyoto University}

\begin{abstract}
Dominant theories assume that moral judgments reflect the individual's personal beliefs, but cross-cultural findings on morality suggest that people in collectivistic and tight cultures may rely on social expectations to evaluate morally relevant actions. Moreover, moral attitudes are flexible, and people may adapt moral values in line with what the members of the host culture value. In the current research, self-construal, tightnesslooseness, and extrinsic moral motives (perceptions that moral acceptability of a given action is something that people are expected to go along with others) were investigated. Japan residents who had never been abroad $(n=73)$ and Japanese sojourners in individualistic and loose cultures (the United States, Canada, France, Germany, and Italy; $\mathrm{n}=50$ ) participated. Results showed that compared with Japan residents, Japanese sojourners reported lower extrinsic moral motives on morally relevant actions concerning communal values. Cultural tightness, but not self-construal, mediated the relationship between culture and extrinsic moral motives ratings. Among sojourners, assimilation and cultural tight- ness predicted higher extrinsic moral motives ratings, whereas length of residence negatively predicted the motives. These results show that people in tight cultures may make moral judgments based on what is perceived as socially appropriate, but not on what is personally important. Also, the research highlights the importance of considering the role of extrinsic moral motives in shaping moral judgments.
\end{abstract}

Keywords: Morality, Cultural tightness, Social expectations 


\section{Introduction}

Within the context of globalization, an abundance of opportunities is available to live and work in another country. In 2017, 867,820 Japan nationals had been living overseas for more than 3 months as Japanese sojourners (Ministry of Foreign Affairs of Japan, 2018). One challenge for newcomers is to learn the culture-specific social rules and act accordingly (Fantini, 2000). Social rules differ by culture, and the following proverb often applies, "when in Rome, do as the Romans do." Because breaking a rule may result in punishments with varying degrees of severity, including ridicule, condescension, or exclusion from the group (Graham et al., 2013), understanding moral values in the host culture is critical for successful cultural adaptation.

Culture may exert an influence on one's views of morality by pressing people to adapt certain values in the form of extrinsic motives (Bardi \& Schwartz, 2003; Schwartz et al., 1997). An extrinsic motive is the individual's perceived control he or she has over his or her own actions in a specific domain (Hofstede, 2001; Vauclair et al., 2015). In the moral domain, people may place moral value on a certain issue because it has been internalized as an important value (intrinsic moral motives). In contrast, they may follow a moral rule because they believe that society expects them to adapt that value (extrinsic moral motives). To reiterate, a moral value may be rated as personally important because it has been internalized or it has been associated with a positive valence by experience. Thus, moral judgments may differ with an extrinsic value motive because people may judge the permissibility of a moral violation in accordance with societal expectations. We set out this study to investigate the relationship between selfconstrual, cultural tightness, and extrinsic moral motives.

\section{Cultural variations in moral judgments: the role of extrinsic moral motives}

In dominant morality theories, three moral systems are described as universal: autonomy, community, and divinity (Rozin et al., 1999; Shweder et al., 1997). The autonomy moral system concerns personal rights and freedom. The community moral system concerns maintaining social order and harmonious relationships. The third system, divinity (i.e., purity), prescribes a view that the body is a holy temple and must be kept pure. The three moral systems are discrete and activate distinctive emotional and behavioral responses when people evaluate the transgressions (Haidt et al., 1993; Rozin et al., 1999).

Culture influences the extent to which people emphasize moral systems, such that some moral values are valued more than others. People in collectivistic cultures tend to show stronger emotional responses to transgressions of the community moral system than people in individualistic cultures (Laham et al., 2009). In many 
collectivistic cultures, including Japan, respect for elders and authority figures are prescribed as a norm, and people acquire communal values during socialization (Graham et al. 2013). When asked to evaluate moral concerns, people in collectivistic cultures tend to focus on the community moral system (Miller et al. 1990). That is, people with an interdependent self-construal attach moral significance to the interpersonal obligation, promoting adherence to community rules.

Furthermore, moral judgments may be influenced by extrinsic moral motives. Moral values may be upheld in one culture because members of the cultural group believe that the values are endorsed by other members (Vauclair et al., 2015). Under some circumstances, people may make moral judgments based on what seems socially approvable, not on their personal value system (Chiu et al., 1997). As a result, people adjust their judgments in accordance with what is perceived as moral. Considering that violations of a social moral value may entail an undesirable consequence (e.g., ostracism), people may attempt to act in line with social expectations (Chiu et al., 1997). As social beings, people are concerned with how others evaluate them, and consequently, moral attitudes are partly maintained by an inclination to present oneself in a manner perceived favorably by others.

Past findings have suggested that the Japanese are more susceptible to perceived desirability in moral judgments, and should show higher extrinsic moral motives than those in independent and loose cultures. Japanese university students showed higher compliance with social norms, compared with the US students (Fukushima et al., 2009). An indigenous Japanese moral value prescribes that in interpersonal situations, conformity is critical to avoid disharmony, and the Japanese tend to approve what is endorsed by others (Honda et al., 2017). In the process of socialization, Japanese mothers encourage their children to be compliant and non-assertive (Conroy et al., 1980). Because Japanese children are taught to behave in manners that promote relational harmony, compared with children in individualistic and loose cultures, they are more concerned with acting in line with what others perceive as moral.

To ascertain what causes the cultural variations in extrinsic moral motives among Japan residents and Japanese sojourners, two socioecological factors have been tested in this study: different modes of self-construal and cultural tightness/ looseness.

\section{Interdependent and independent self-construal}

People in collectivistic cultures tend to have an interdependent self-construal, and people in individualistic cultures tend to have an independent cultural self-construal (Kitayama \& Markus, 1999; Singelis, 1994). An individual with an interdependent selfconstrual perceives the self as part of a large social unit, and relational harmony, mutual 
obligations, and respect for social rank are valued. In interdependent cultures, moral concern is related to promoting a collective goal sometimes by sacrificing a personal goal (Schwarz, 1990). By contrast, an individual with an independent self-construal perceives the self as autonomous and detached from others, and personal autonomy, self-fulfillment, and uniqueness are valued (Kitayama \& Markus, 1999). In individualistic cultures, a morally relevant question is whether a personal right is protected rather than whether an interpersonal duty is fulfilled (Miller et al. 1990). Interdependent and independent self-construals influence attitudes, beliefs, values, and behaviors in different cultures (Haidt et al., 1993; Kitayama \& Markus, 1999; Shweder et al., 1997) as well as values in the moral domain (Gollwitzer \& Bücklein, 2007).

Moral attitudes fluctuate as a function of self-construal (Gollwitzer and Bücklein 2007; Graham et al., 2013; Haidt et al., 1993; Laham et al., 2009; Shweder et al., 1997). Violations of moral rules elicit more contempt and punitive judgments among people with a collectivistic (e.g., Indian) orientation than people with individualistic cultural orientations (e.g., Britain and the United States: Laham et al., 2009; Miller et al., 1990). People with an interdependent self-construal are sensitive to the moral rights of others and consider injustice unjust (Gollwitzer \& Bücklein, 2007). By contrast, independent self-construal is associated with a weak or no sense of morality and selfish choices (Gollwitzer \& Bücklein, 2007). However, the results are mixed for the link between independent self-construal and (un)ethical behavior (Cojuharenco et al., 2012). Investigations on culture, self-construal, and morality have revealed that for people with an interdependent self-construal, but not an independent self-construal, interpersonal responsibility (i.e., self-sacrifice for the well- being of others) carries moral significance.

\section{Cultural tightness-looseness}

Another socioecological factor that shapes morality is cultural tightness and loose- ness. In tight cultures, such as Japan (Gelfand et al., 2011; Uz, 2015), people perceive rules and prescriptions as definite, and strong compliance is normalized. Societal institutions and practices impose high constraints on social behavior, and people have higher self-control, a need for structure, and a cautious thinking style (Gelfand et al., 2011). By contrast, loose cultures perceive that social norms are flexible and show more tolerance for deviance compared with tight cultures. The tight-loose cultural variation originates from different ecologies, such as survival challenges (e.g., prevalence of human diseases, resource scarcity, and natural disaster: Gelfand et al., 2011), and influences moral attitudes (Mrazek et al., 2013).

\section{Aim}


In this study, self-construal, cultural tightness, and extrinsic moral motives among Japan residents and Japanese sojourners were investigated to test the hypothesis that societal differences in cultural tightness-looseness and self-construal would explain the relationship between culture and extrinsic moral motives. Studies have suggested that being immersed in a new culture changes an individual's value system, including moral values, and personality traits (Güngör et al., 2013). Because morality is central to social life (Haidt, 2008), to fit in, people should absorb values accepted in the immediate environment. To investigate how living in a new culture shapes extrinsic moral motives, the effects of cultural assimilation, length of residence, and language proficiency on extrinsic moral motives among Japanese sojourners were also investigated. Based on the relevant theories, the following hypotheses were tested:

\section{Hypothesis 1a}

Compared with Japan residents, Japanese sojourners will be more individualistic.

\section{Hypothesis $1 b$}

Japan residents will perceive that Japanese society is tighter than Japanese sojourners.

\section{Hypothesis 2}

Cultural tightness and self-construal (independent, interdependent) will mediate the relationship between culture (place of residence) and extrinsic moral motives (perceived social desirability in moral judgment) in the community moral system.

\section{Hypothesis 3}

Among Japanese sojourners, length of residence, language proficiency, and assimilation to the host culture will predict higher social expectation ratings.

\section{Methods}

\section{Participants}

Using Fritz and MacKinnon's sample size guidelines (Fritz and MacKinnon 2007), a minimum of 71 would be needed to detect a medium mediation effect with $80 \%$ power with bias-corrected bootstrapping. Based on the results, we aimed to collect a total of 100 participants (50 for each group).

\section{Japan residents}

A total of 73 Japanese citizens who were registered in Lancers participated in exchange for 100 yen (approximately USD 1) as the reimbursement $\left(M_{\text {age }}=39.77, S D=\right.$ 7.69 , female $=61.6 \%$ ). Lancers is one of the major crowdsourcing services in Japan and considered a Japanese alternative to Amazon's MTurk platform. Using one prescreening question ("Have you been abroad for more than 3 months?"), we recruited individuals 
who had never been in contact with a different culture for longer than 6 months. If the individual failed to pass the screening question, he or she no longer had access to the survey page.

\section{Japanese sojourners}

A total of 50 Japan-born temporary or permanent residents in relatively more individualistic and loose countries (the United States, Canada, France, Germany, and Italy: Gelfand et al. 2011; Uz 2015) participated for an opportunity to win an Amazon gift card $\left(M_{\text {age }}=41.04, S D=9.48\right.$, female $\left.=80 \%\right)$. Based on the tight- ness-looseness scores across nations (Gelfand et al., 2011; Uz, 2015), we targeted temporary Japanese residents in Western countries characterized as having higher individualism and lower tightness scores than Japan. To collect data from Japanese residents in the target countries, we posted free ads on online Japanese community boards.

All the sojourners were originally from Japan. The IP addresses were looked up to ensure that the sojourner participants were living where they indicated in the survey. Reasons for living in the other country varied (26\% because a family member was transferred to another branch; $26 \%$ because of marriage; $22 \%$ because of study abroad program; $14 \%$ because of job transfer; and other was $12 \%$ ). Table 1 presents sample characteristics.

\section{Materials}

After agreeing to participate, participants accessed a survey page online and answered the following psychological scales and demographic questions at their own paces.

\section{Self-construal}

The Independent and Interdependent Self-Construal scale (IIS-C: Takata, 2000) was used to assess the level of independence and interdependence of an individual's self- concept. The 20-item scale comprised two subscales, independent and interdepend- 
ent self, and a seven-point Likert scale, from 1 (strongly disagree) to 7 (strongly agree). Example scale items of the independent subscale were as follows: "I enjoy being unique and different from others in many respects," "I do my own thing, regardless of what others think," and "I feel it is critical to act as an independent per- son." Example items of the interdependent subscale were as follows: "I will sacrifice my self-interest for the benefit of the group I am in," "I should take into consideration my parents' advice when making education/career plans," and "My happiness depends on the happiness of those around me."

We used this scale instead of Singelis' (1994) scale because the latter scale has been found to be low in convergent validity (Levine et al. 2003) and culturally inappropriate for East Asian samples (Takata, 2000). By contrast, the IIS-C scale is suitable for both Western and Eastern samples, and this has been validated crossculturally using Australian, Canadian, and Japanese samples as well as Asian international students in Japan (Takata, 2000). Cronbach alphas were .81 (independent selfconstrual) and .83 (interdependent self-construal) for Japan residents and .86 and .90 for Japanese sojourners.

\section{Cultural tightness}

A six-item scale (Gelfand et al., 2011) was used to assess the extent to which an individual perceives the numbers of social norms, overall compliance, and tolerance for deviance in his/her country of residence. Examples of the items are as follows: "There are many social norms that people are supposed to abide by in [country of residence]," "People in [country of residence] almost always comply with social norms," and "In this country, if someone acts in an inappropriate way, others will strongly disapprove." Cronbach alphas were .61 for Japan residents and .70 for Japanese sojourners.

\section{Extrinsic moral motives}

A scale was adapted from the literature to measure the extent to which participants perceived societal pressure on their moral judgments related to community rules (Kristiansen \& Hotte, 1996; Vauclair et al., 2015). Three community moral system items that depicted moral transgressive actions, from Shweder et al. (1997), were presented ("Leave work an hour early on a daily basis when no one else is around", "Refuse to give up your seat on the bus to a disabled old lady", and "Speak to your supervisor in the same way you talk to your friend."). The instructions were as follows: "Please decide whether it is your free choice or societal expectation that deter- mines how morally desirable each action is in [country name]." The country name "Japan" or "[Country of residence]" was matched to the participant sample to avoid reference bias. The response anchors were adapted from Vauclair et al. (2015) and ranged from 0 
(something that is my free choice) to 5 (something that I am expected to go along with others). Higher scores indicated that participants perceived stronger influences of social expectations on moral choices. Cronbach alphas were .72 for Japan residents and .73 for Japanese sojourners.

\section{Demographics}

Both Japan residents and Japanese sojourners responded to questions on conservativeness ( $1=$ very liberal; $9=$ very conservative), perceived SES $(10=$ the lowest ladder; $1=$ the highest ladder), their religiosity ( $1=$ religion is extremely important; $9=$ not at all important), and frequency of religious activities ( $1=$ several times a week; $9=$ never). The three demographic factors (political conservativeness, perceived SES, and religiosity) have been found to influence morality (Graham et al., 2013; Haidt et al., 1993).

\section{Cultural assimilation}

For Japanese sojourners, a subscale of the East Asian Acculturation Measure (Barry 2001) was included to assess the extent to which Japanese residents have assimilated to a host culture. Assimilation is one acculturation strategy, namely, newcomers voluntarily abandon their old cultural selves and absorb new values of the host culture (Berry and Sam 1997). Because the process of moralization involves transforming non-moral issues into the morally significant (Rozin et al. 1999), the assimilation subscale was used. Examples of the items are as follows: "I write better in English than Japanese," "I get along better with native speakers than Japanese," and "Most of my friends at work/school are native speakers." Responses ranged from 1 (disagree strongly) to 7 (agree strongly). Additionally, participants were asked to indicate the length of stay (in years) and self-rated language proficiency ( $1=$ very fluent; $10=$ not fluent at all). Cronbach alpha was 0.82 .

\section{Results}

\section{Preliminary analyses}

Table 2 presents means, standard deviations, and reliability coefficients (Cronbach alphas) of constructs among Japanese residents and sojourners. First, correlations between variables were computed. Theoretically consistent (Gelfand et al. 2011), cultural tightness was also significantly correlated with perceptions that moral actions are influenced by social pressure, $r=.28, p<.01$. Interdependent, but not individualistic, orientation was significantly correlated with tightness and social expectations (tightness: $r=.37, p<.001$; social expectations: $r=0.24, p<.01$ ).

For demographic variables (religiosity, frequency of religious activities, conservativeness), Spearman's correlations were computed. Consistent with findings in 
the literature on political ideology and moral judgments (Graham et al. 2013), cultural tightness showed a significant correlation with conservativeness, $r=0.34, p<.001$. Lower SES was positively correlated with tightness scores, $r=.39, p<.001$. Table 3 presents intercorrelations for key constructs.

Table 2

Means, Standard Deviations, Cronbach Alphas of Key Variables Among Japan Residents and Sojourners

\begin{tabular}{|c|c|c|c|c|c|}
\hline & \multicolumn{2}{|c|}{ Japan residents } & \multicolumn{2}{|l|}{ Sojourners } & \multirow[t]{2}{*}{$F$} \\
\hline & $M(S D)$ & $\alpha$ & $M(S D)$ & $\alpha$ & \\
\hline $\begin{array}{l}\text { Perceptions of social } \\
\text { expectations }\end{array}$ & $8.85(5.25)$ & .72 & $6.08(5.92)$ & .73 & $7.27^{*}$ \\
\hline Cultural tightness & $25.10(3.43)$ & .61 & $20.96(4.62)$ & .70 & $32.46 * *$ \\
\hline Independent S-C & $41.97(7.81)$ & .81 & $49.16(11.12)$ & .86 & $17.61 * *$ \\
\hline Interdependent $\mathrm{S}-\mathrm{C}$ & $49.55(7.18)$ & .83 & $45.18(10.80)$ & .90 & $7.20^{*}$ \\
\hline
\end{tabular}

$F$ one-way ANOVA comparing means between Japan residents and Japanese sojourners, $S$ - $C$ self-construals

$* p<.01, * * p<.001$

\section{Group comparisons}

To test Hypothesis $1 \mathrm{a}$ and $1 \mathrm{~b}$, a series of $\mathrm{t}$ tests were performed. Results showed that Japan residents $(M=49.55, S D=7.18)$ were significantly more collectivistic than Japanese sojourners $(M=45.18, S D=10.80), t(76.25)=2.49, p=.02, d=0.48$. By contrast, Japanese sojourners $(M=49.16, S D=11.12)$ were more individualistic than Japan residents $(M=41.97, S D=7.81), t(79.25)=-3.92, p<.001, d=0.75$. These results supported Hypothesis $1 \mathrm{a}$ and $1 \mathrm{~b}$.

For demographic variables (political conservativeness, SES, and religiosity), Mann-Whitney tests were run. Compared with Japanese sojourners, Japan residents were more conservative and lower in SES (conservativeness: $Z=-5.12, p<.001, r$ $=.46$; SES: $Z=3.19, p<.01, r=0.29)$. As shown in Table 1, more than half of Japan residents and Japanese sojourners indicated their religion as "nothing in particular" or "other". the two groups did not significantly differ in religiosity and the frequency of religious activities (religiosity: $Z=-1.07, p=.29$; frequency of religious activities: $Z$ $=-1.08, p=.28)$. In the subsequent analyses, conservativeness and SES were entered as covariates to control the effects. 
Table 3

Intercorrelations for Key Variables

\begin{tabular}{|c|c|c|c|c|}
\hline & 1 & 2 & 3 & 4 \\
\hline $\begin{array}{l}\text { 1. Perceptions of social } \\
\text { expectations }\end{array}$ & & $.28 * *$ & -.12 & $.23^{*}$ \\
\hline 2. Cultural tightness & & & -.05 & $.37 * * *$ \\
\hline 3. Independent $\mathrm{S}-\mathrm{C}$ & & & & $-.20 *$ \\
\hline 4. Interdependent S-C & & & & \\
\hline
\end{tabular}

Note. $p^{*}<.05, p^{* *}<.01, p^{* * *}<.001$.

\section{Mediation analyses}

To test Hypothesis 2, mediation analyses were run, using the PROCESS Macro program developed by Preacher and Hayes (2004). Because mediating variables should be correlated with the predictor (culture) and outcome variables (extrinsic moral motives), independent self-construal was not included in the model. For interpretation, the mediation effect was significant if the $90 \%$ confidence interval did not include zero.

Hypothesis 2 was supported for cultural tightness as a mediator. The results showed that cultural tightness mediated the relationship between culture and extrinsic moral motives, bootstrap $=-0.563, \mathrm{SE}=0.352$, CI $[-1.403,-0.035]$. Interdependent self-construal was not a significant mediator, bootstrap $=-0.231, \mathrm{SE}=0.222$, CI $[-0.761,0.091]$. Figure 1 depicts the results.

\section{Predicting extrinsic moral motives among Japanese residents overseas}

To test Hypothesis 3, hierarchical regression analyses were run. In the first step, subjective SES and conservatism were entered as covariates. In the second step, language proficiency, length of stay (in years), cultural tightness, and assimilation were entered. Given the results of correlation and mediation analyses, independent and interdependent self-construals were not included in the model.

Hypothesis 3 was partially supported. In the final model, length of stay, cultural tightness, and assimilation emerged as significant predictors. Cultural tightness and assimilation positively predicted higher extrinsic moral motives (cultural tightness: $\beta=$ $0.29, \mathrm{SE}=0.12, p=.04,95 \% \mathrm{CI}[0.013,0.493]$; assimilation: $\beta=0.40, \mathrm{SE}=0.07, p=$ $0.01,95 \%$ CI $[0.044,0.323])$. By contrast, length of stay negatively predicted the outcome. The final model was significant, $F(6,41)=2.77, p=.02$ with $R^{2}$ adjusted $=.18$. Results are provided in Table 4. 


\section{Figure 1}

Mediation Model Predicting Extrinsic Morality Values

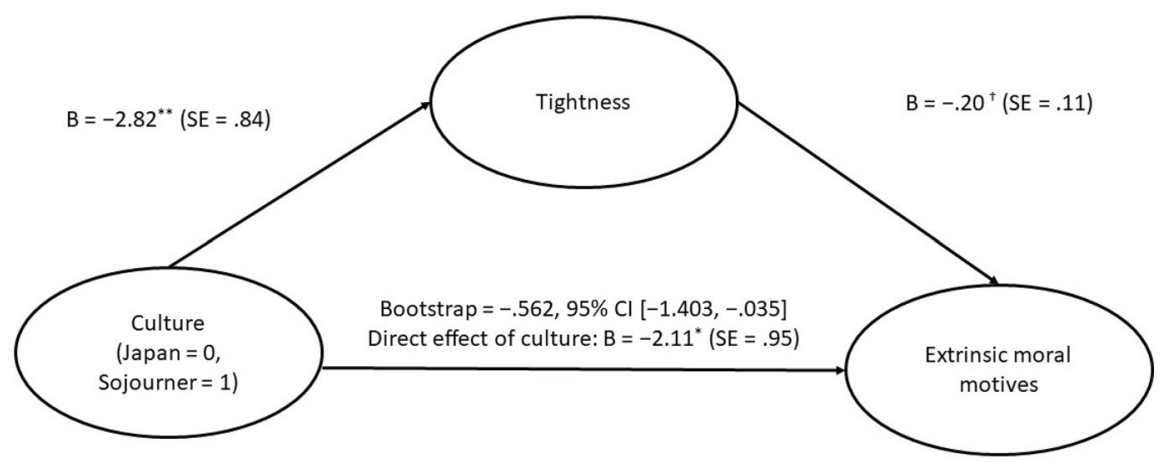

Note. Culture was coded as Japan residents $=0$ and Japanese sojourners $=1$. $p^{\dagger}<.1, p^{*}<.05, p^{* *}<.01, p^{* * *}<.001$.

\section{Table 4}

Regressions Predicting Perception of Social Expectations Among Japanese Sojourners

\begin{tabular}{|c|c|c|c|c|}
\hline & \multicolumn{2}{|r|}{ Step 1} & \multicolumn{2}{|r|}{ Step 2} \\
\hline & $\beta$ & $\mathrm{CI}$ & $\beta$ & CI \\
\hline SES & -.10 & $-.976, .479$ & -.25 & $-1.367, .127$ \\
\hline Conservativism & -.17 & $-.894, .237$ & $-.24 \dagger$ & $-.992, .075$ \\
\hline Language proficiency & & & .27 & $-.102, .887$ \\
\hline Length of stay & & & $-.29^{*}$ & $-.232,-.005$ \\
\hline Cultural tightness & & & $.29^{*}$ & $.904,1.106$ \\
\hline Assimilation & & & $.40^{*}$ & $.044, .323$ \\
\hline$R^{2}$ & & -- & & $25^{*}$ \\
\hline
\end{tabular}

\section{Discussion}

This research aimed to investigate the relationships between two modes of selfconstrual (interdependent and independent), cultural tightness, and extrinsic moral motives (perceived social pressure on moral choices) under the assumption that people adapt moral values in line with what is valued in the immediate context. Specifically, the aim was to show that unlike the assumption that moral judgments are based on personal values, people living in a collectivist culture make moral judgments based on extrinsic moral motives, that is, what is perceived as morally acceptable by others. For this purpose, Japan residents who had never been abroad and Japanese sojourners in individualistic and loose countries (the United States, Canada, France, Germany, and Italy) participated. Japan resi- dents and Japanese sojourners differed significantly in the number of 
constructs, including independent and interdependent self-construals, cultural tightness, and extrinsic moral motives. Additionally, cultural tightness explained the relation- ship between culture (country of residence) and extrinsic moral motives in the community domain.

The results confirmed findings in the literature on acculturation that sojourners become more like the members of the host culture (Güngör et al., 2013). In this study, compared with Japan residents, Japanese sojourners in individualistic and loose cultures reported higher levels of individualism and lower extrinsic moral motives in the community moral system. Given that more than half of the Japanese sojourners indicated that they had migrated to another country with no choice (e.g., a family member was transferred to another branch), it could be likely that they have become individualistic and to perceive that moral judgments are based on personal choices, rather than social expectations. This result supports a brain study demonstrating that engaging in a scripted set of cultural practices for a prolonged time changes the brain circuits, and over time, and the individual becomes acculturated to the host culture (Kitayama \& Uskul, 2011). This study suggests that living in a different culture may affect an individual's selfconstrual and perceptions of social pressure on how they behave in the context concerning the moral domain of community. Thus, Japanese sojourners have been accustomed to the local culture to fit into the immediate context, and behaving in line with the cultural values may have gradually changed their self-construal and moral extrinsic moral motives.

This study also showed that cultural variations in one aspect of moral attitudes are explained by cultural tightness. Partially supporting Hypothesis 2, cultural tight- ness, which is the perceived strength of social norms and the degree of compliance, explained the relationship between culture and extrinsic moral motives. A traditional approach to human morality assumed that morality is a personal matter, and the individual makes moral judgments based on personal beliefs. However, results of this study showed that people in tight cultures may evaluate moral transgressions based on what is perceived as socially acceptable, but not on what is personally valuable. This is in line with past findings that in non-Western cultures, morality is interconnected with cultural mores and values (Laham et al., 2009; Miller et al. 1990). This result suggests that people cultivate moral values in accordance with how they perceive that social norms are sanctioned in the culture.

Cultural tightness, but not interdependent self-construal, mediated the link between culture and social expectations in the community domain. We proposed two explanations for this. One explanation is that cultural tightness directly relates to morality. In each cultural context, people confront unique ecological challenges, and cultural 
tightness is one strategy for managing social order (Gelfand et al., 2011). Another explanation is that the measure used in this study did not capture two versions of collectivism: North American and East Asian collectivism. People in individualistic and collectivistic cultures are gregarious but in different manners: they are both collectivistic to some extent but use different strategies to maintain a sense of the collective self (Yuki 2003). At this point, no psychological scales measure the two versions of collectivism. It could be that Japanese sojourners may have shifted their collectivistic orientation to the North American from the East Asian version. Future studies should focus on the third dimension of self-construal to clarify its role in shaping not only the cognitive component of moral attitudes, but also the affective and behavioral components.

Among Japanese sojourners, cultural assimilation with the host culture predicted higher social expectation ratings. Participants who attempted to assimilate with the host culture tended to perceive that morality-related actions were influenced by social expectations, rather than personal choices. Considering cultural assimilation is linked to few interpersonal difficulties (Ward \& Rana-Deuba, 1999), it may be that adaptation of new values in the moral domain helps individuals oriented toward assimilation avoid interpersonal conflicts that arise from deviations from a norm in the new cultural context.

By contrast, length of stay negatively predicted outcome. In this study, length of stay in the host country, but not self-reported language proficiency, predicted lower social expectation ratings. This result suggests that Japanese sojourners may begin to make moral choices based on personal values, rather than on social expectations as the duration of their residency in the host culture increases. Further research should investigate the process through which sojourners replace the existing moral value system with the new one in the host culture by using a longitudinal research design. Clarifying how sojourners adapt new moral attitudes in the process of acculturation is important for understanding how a conflict between old and new moral values may be resolved and the individual makes a smooth transition to the new cultural context.

\section{Limitations and future directions}

To further clarify the effects of socio-cultural adaption on the malleability of moral values, particularly moralization of certain issues, two limitations are note- worthy. First, further research should investigate how types of acculturation influence adaptation of new moral values. There are large variations in which people acculturate themselves in a new culture, and acculturation patterns predict diverse outcomes in adaption (Berry and Sam 1997). Does successful adaption of moral values in the host culture increase well-being? Because a specific type of cultural adaption predicts higher subjective well-being, we expected that in the moral domain, too, a pattern of adapting moral values would be 
associated with perceived intercultural competence and well-being.

Second, variations in moral judgments are found between and within nations (Haidt et al., 1993). This research focused only on cultural variations, but further research should also focus on within-nation factors that influence individuals' moral attitudes. Demographic variables, such as age, social class, and political preference, have been found to also influence the extent to which people embrace the three moral codes. Moreover, the extent to which demographic variables influence moral judgment may depend on culture. In North America and many parts of Europe, political preference is a strong predictor of attitudes toward various social and moral issues (Graham et al., 2013). By contrast, liberal and conservative orientations have little to say about an individual's opinions on social and moral issues in many parts of the world, including Japan. Similarly, we expect that religious beliefs may exert great impacts on judgments and behavior in many regions, but not so where many people describe themselves as non-religious or even atheists. Notably, one of the divinity items constructed by Shweder et al. (1997) is immoral in Islamic cultures, where females are prohibited from touching a non-relative of the opposite sex. Given the complex structure of morality with the various factors affecting how individuals construe the moral world, we suggest that further research should include several collectivistic and individualistic cultures and use culturally sensitive moral items to measure morality.

Lastly, future studies should use a longitudinal research design to investigate the process through which sojourners/immigrants adapt moral values sanctioned in the host culture and its relation to subjective wellbeing. Adaptation of new moral values may lead to successful social functioning in a new culture. How- ever, it does not necessarily imply that holding onto old values should be avoided. Within the context of globalization, an individual may attempt to embrace moral as well as non-moral values of two cultures. Further research should investigate not only the process of moralization but the process through which an individual integrates new moral values into the existing moral system without compromising one for another.

\section{Concluding Remarks}

This study shows that cultural variations in extrinsic moral motives (perceived desirability in moral judgment) are explained by cultural tightness. This finding suggests that people in tight cultures, including Japan, make moral judgments by evaluating societal acceptability rather than personal beliefs. There may be some aspects of morality in the non-Western context missing from the dominant theories of morality that are based on the premise that moral judgments reflect the individual's moral values. 


\section{References}

Barry, D. T. (2001). Development of a new scale for measuring acculturation: The East Asian Acculturation Measure (EAAM). Journal of Immigrant Health, 3, 193-197. doi:10.1023/A:1012227611547

Berry, J.W., \& Sam, D.L. (1997). Acculturation and adaptation. In J. W. Berry, M. H. Segall, \& C. Kagitcibasi (Eds.), Handbook of cross-cultural psychology, Vol. 3: Social behaviour and applications (2nd Ed.; pp. 291-326). Boston, MA: Allyn \& Bacon.

Chiu, C., Dweck, C. S., Tong, J. Y., \& Fu, J. H. (1997). Implicit theories and concepts of morality. Journal of Personality and Social Psychology, 73, 923-940. doi:10.1037/0022-3514.73.5.923

Cojuharenco, I., Shteynberg, G., Gelfand, M., \& Schminke, M. (2012). Self-construal and unethical behavior. Journal of Business Ethics, 109, 447-461. doi:10.1007/s10551-01101139-8.

Conroy, M., Hess, R. D., Azuma, H., \& Kashiwagi, K. (1980). Maternal strategies for regulating children's behavior: Japanese and American families. Journal of CrossCultural Psychology, 11, 153-172. doi:10.1177/0022022180112002

Dahl, A., \& Freda, G. F. (2017). How young children come to view harming others as wrong: A developmental analysis. In J. A. Sommerville \& J. Decety (Eds.), Social cognition: Development across the life span (pp. 151-184). New York: Routledge.

Fantini, A. E. (2000). A central concern: Developing intercultural competence. Retrieved from

http://citeseerx.ist.psu.edu/viewdoc/download?doi=10.1.1.117.8512\&rep=rep1\& type $=$ pdf\#page $=33$

Fukushima, M., Sharp, S., \& Kobayashi, E. (2009). Bond to society, collectivism, and conformity: A comparative study of Japanese and American college students. Deviant Behavior, 30, 434-466. doi:10.1080/01639620802296212

Gelfand, M. J., Raver, J. L., Nishii, L., Leslie, L. A., Lun, J., Lim, B. C., et al. (2011). Differences between tight and loose cultures: A 33-nation study. Science, 332, 1100-1104. doi:10.1126/science.1197754

Gollwitzer, M., \& Bücklein, K. (2007). Are "we" more punitive than "me"?: Selfconstrual styles, justice-related attitudes, and punitive judgments. Social Justice Research, 20, 457-478. doi:10.1007/s11211-007-0051-y

Graham, J., Haidt, J., Koleva, S., Motyl, M., Iyer, R., Wojcik, S., \& Ditto, P. H. (2013). Moral Foundations Theory: The pragmatic validity of moral pluralism. Advances in Experimental Social Psychology, 47, 55-130. doi:10.1016/B978-0-12-407236- 


\section{$7.00002-4$}

Güngör, D., Bornstein, M. H., De Leersnyder, J., Ceulemans, E., \& Mesquita, B. (2013). Acculturation of personality: A three-culture study of Japanese, Japanese Americans, and European Americans. Journal of Cross-Cultural Psychology, 44, 701-718. doi:10.1177/0022022112470749

Haidt, J. (2008). Morality. Perspectives on Psychological Science. 3, 65-72. doi:10.1111/j.1745-6916.2008.00063.x

Haidt, J., Koller, S., \& Dias, M. (1993). Affect, culture, and morality, or is it wrong to eat your dog? Journal of Personality and Social Psychology, 65, 613-628. doi:10.1037/0022-3514.65.4.613

Honda, S., Ishimaru, A., Utsunomiya, S., Yamane, T., Oda, M., Sakamoto, K., Oe, Y., Kobayashi, H., Arima, T., Kidera, A., \& Kosugi, K. (2017). Considering the relation between the Haidt's Moral Foundations Theory and Japanese morality through developing a new scale. Bulletin of the Faculty of Education, Yamaguchi University, 66, 95-106. (in Japanese)

Kitayama, S., \& Markus, H. R. (1999). Yin and yang of the Japanese self: The cultural psychology of personality coherence. In D. Cervone \& Y. Shoda (Eds.), The coherence of personality: Social cognitive bases of personality consistency, variability, and organization (pp. 242-302). New York: Guilford.

Kitayama, S., \& Uskul, A. K. (2011). Culture, mind, and the brain: current evidence and future directions. Annual Review of Psychology, 62, 419-49. doi:10.1146/annurev-psych-120709-145357

Laham, S., Chopra, S., Lalljee, M., \& Parkinson, B. (2009). Emotional and behavioural reactions to moral transgressions: Cross-cultural and individual variations in India and Britain. International Journal of Psychology, 45, 64-71. doi:10.1080/00207590902913434

Miller, J. G., Bersoff, D. M., \& Harwood, R. L. (1990). Perceptions of social responsibilities in India and in the United States: Moral imperatives or personal decisions? Journal of Personality and Social Psychology, 58, 33-47. doi:10.1037/0022-3514.58.1.33

Ministry of Foreign Affairs of Japan (2018). Annual Report of Statistics on Japanese Nationals

Overseas.

Retrieved

from https://www.mofa.go.jp/mofaj/files/000368753.pdf

Mrazek, A. J., Chiao, J. Y., Blizinsky, K. D., Lun, J., \& Gelfand, M. J. (2013). The role of culture-gene coevolution in morality judgment: Examining the interplay between tightness-looseness and allelic variation of the serotonin transporter gene. Culture 
and Brain, 1(2-4), 100-117. doi:10.1007/s40167-013-0009-x

Preacher, K. J., \& Hayes, A. F. (2004). SPSS and SAS procedures for estimating indirect effects in simple mediation models. Behavior Research Methods, Instruments, \& Computers, 36, 717-731. doi: 10.3758/BF03206553

Rozin, P., Lowery, L., Imada, S., \& Haidt, J. (1999). The CAD triad hypothesis: A mapping between three moral emotions (contempt, anger, disgust) and three moral codes (community, autonomy, divinity). Journal of Personality and Social Psychology, 76, 574-586. doi:10.1111/1467-9280.00139

Shweder, R. A., Much, N. C., Mahapatra, M., \& Park, L. (1997). The "big three" of morality (autonomy, community, and divinity), and the "big three" explanations of suffering. In A. Brandt \& P. Rozin (Eds.), Morality and health (pp. 119-169). New York, NY: Routledge.

Singelis, T. M. (1994). The measurement of independent and interdependent selfconstruals. Personality and Social Psychology Bulletin, 20, 580-591. doi:10.1177/0146167294205014

Takata, T. (2000). On the scale for measuring independent-interdependent view of self. Bulletin of Research Institute, Nara University, 8, 145-163 (Japanese).

Uz, I. (2015). The index of cultural tightness and looseness among 68 countries. Journal of Cross-Cultural Psychology, 46, 319-335.doi: 10.1177/0022022114563611

Vauclair, C.-M., Fischer, R., Ferreira, M.C., Guerra, V., Hössler, U., Karabati, S., Kirk de Carvalho Filho, M., Porto, J.B., Lopez Reyes, M., Rytkönen, J. \& Spiess, E. (2015). What kinds of value motives guide people in their moral attitudes?: The role of personal and prescriptive values at the culture-level and individual-level. Journal of Cross-cultural Psychology, 46, 211-228. doi:10.1177/0022022114557487

Ward, C, \& Rana-Deuba, A. (1999). Acculturation and adaptation revisited. Journal of Cross-Cultural Psychology, 30, 373-392. doi: 10.1177/0022022199030004003

Yuki, M. (2003). Intergroup comparison versus intragroup cooperation: A cross-cultural examination of social identity theory in North American and East Asian cultural contexts. Social Psychology Quarterly, 66, 166 -183. doi:10.2307/1519846 